\title{
Heavy metals content in soils and cocoa tissues in Magdalena department Colombia: emphasis in cadmium*
}

\author{
Sonia Esperanza Aguirre-Forero \\ Docente Asociada Universidad del Magdalena, Santa Marta - Colombia. \\ saguirre@unimagdalena.edu.co (D) http://orcid.org/0000-0002-6975-1940 \\ Nelson Virgilio Piraneque-Gambasica \\ Docente Titular Universidad del Magdalena, Santa Marta - Colombia. \\ npiraneque@unimagdalena.edu.co (1) http://orcid.org/0000-0002-4264-9428 \\ José Rafael Vásquez-Polo \\ Docente Asociado Universidad del Magdalena, Santa Marta - Colombia. \\ jvasquez@unimagdalena.edu.co (D) http://orcid.org/0000-0002-2485-8226
}

A B S T R A C T

Cocoa (Theobroma cacao L.) is a species originating from the humid tropics. Over $70,000 \mathrm{~km}^{2}$ worldwide is dedicated to growing cocoa, and approximately $30 \%$ of its global production is concentrated in the equatorial regions of Central and South America, the Antilles and tropical Asia. The demand for cocoa is growing significantly, but the presence of cadmium (Cd) in the species is a potential problem limiting its commercialization. The present study determined the $\mathrm{Cd}, \mathrm{Ni}, \mathrm{Pb}$ and $\mathrm{Cr}$ content in two cocoa-producing regions in northern Colombia. Foliage (leaf, bean and shell) and soil were analyzed. The mean $\mathrm{Ni}, \mathrm{Pb}$ and $\mathrm{Cr}$ content in the plant tissue did not exceed the maximum permissible limits set by the United States Environmental Protection Agency (EPA). The mean Cd content in the beans was $0.51 \mathrm{mg} \mathrm{kg}^{-1}$ in region I and $0.66 \mathrm{mg} \mathrm{kg}^{-1}$ in region 2, which are considered risky per reports from the European Union and restrict the product's export. These results serve as a reference for future research on cocoa.

KEYWORDS

\section{Contenido de metales pesados en suelos y tejidos de cacao en el departamento del Magdalena, Colombia: énfasis en cadmio}

RES U M E N

El cacao (Theobroma cacao L.) es una especie originaria de los trópicos húmedos. Más de 70,000 km² en todo el mundo están dedicados a su cultivo y aproximadamente el 30\% de su producción mundial se concentra en las regiones ecuatoriales de América Central y del Sur, las Antillas y Asia tropical. La demanda de cacao está creciendo significativamente, pero la presencia de cadmio (Cd) en la especie es un problema potencial que limita su comercialización. El presente estudio determinó el contenido de Cd, $\mathrm{Ni}$, Pb y Cr en

* Artículo de investigación científica resultado del proyecto de investigación Evaluación de contaminantes en Cacao, contenidos de Cd y otros metales pesados Santa Marta Colombia, financiado por la Vicerrectoría de Investigación.

Este es un artículo Open Access bajo la licencia BY-NC-SA (http://creativecommons.org/licenses/by-nc-sa/4.0/)

Cómo citar este artículo: AGUIRRE-FORERO, Sonia Esperanza; PIRANEQUE-GAMBASICA, Nelson Virgilio; VÁSQUEZ-POLO, José Rafael. Heavy metals content in soils and cocoa tissues in Magdalena department Colombia: emphasis in cadmium. En: Entramado. Enero - Junio, 2020 vol. I6, no. I, p. 298-310 https://doi.org/10.18041/1900-3803/entramado.2.6753 
dos regiones productoras de cacao en el norte de Colombia. Se analizaron el tejido (hoja, frijol y cáscara) y el suelo. El contenido medio de $\mathrm{Ni}$, Pb y Cr en el tejido vegetal no excedió los límites máximos permisibles establecidos por la Agencia de Protección Ambiental (EPA) de los Estados Unidos. El contenido medio de Cd en los frijoles fue de $0,51 \mathrm{mg} \mathrm{kg}^{-1}$ en la región I y $0,66 \mathrm{mg} \mathrm{kg}^{-1}$ en la región 2, que se consideran riesgosos según los informes de la Unión Europea y restringen la exportación del producto. Estos resultados sirven como referencia para futuras investigaciones sobre el cacao.

Palabras clave

\section{Teor de metais pesados em solos e tecidos de cacau no departamento de Magdalena, Colômbia: ênfase no cádmio}

RES U MO

O cacau (Theobroma cacao L.) é uma espécie originária dos trópicos úmidos. Mais de 70.000 km² em todo o mundo são dedicados à sua cultura e aproximadamente $30 \%$ de sua produção global está concentrada nas regiões equatoriais da América Central e do Sul, Antilhas e Ásia tropical. A demanda por cacau está crescendo significativamente, mais a presença de cádmio (Cd) nas espécies é um problema potencial que limita sua comercialização. $\mathrm{O}$ presente estudo determinou o teor de $\mathrm{Cd}$, $\mathrm{Ni}$, $\mathrm{Pb}$ e $\mathrm{Cr}$ em duas regiões produtoras de cacau no norte da Colômbia. A folhagem (folha, feijão e casca) e o solo foram analisados. $O$ teor médio de $\mathrm{Ni}$, Pb e Cr no tecido vegetal não excedeu os límites máximos permitidos estabelecidos pela Agência de Proteção Ambiental dos Estados Unidos (EPA). O conteúdo médio de Cd nos grãos foi de $0,51 \mathrm{mg} \mathrm{kg}^{-1}$ na região I e 0,66 $\mathrm{mg} \mathrm{kg}^{-1}$ na região 2, que são considerados de risco por relatórios da União Europeia e restringem a exportação do produto. Esses resultados servem como referência para futuras pesquisas sobre cacau.

Palavras-chave

Grãos de cacau; segurança alimentar; metais pesados; Theobroma cacao L; poluentes do solo

\section{Introduction}

Cocoa (Theobroma cacao L.), a species native to the humid tropics of Central and South America, has more than $70,000 \mathrm{~km}^{2}$ worldwide dedicated to its cultivation. Approximately $30 \%$ of its production is concentrated in Central and South America, the Antilles and the tropical zones of Asia (Kongor et al., 2016; Ramírez Gil, 2016), with production of 47 million tons (ICCO, 20I8). Cadmium (Cd) presence in cocoa fruit has been reported in Peru, Ecuador and Colombia, but only some of the territory is believed to be contaminated; thus, the environment must be analyzed to improve the availability and quality of this information. $\mathrm{Cd}$ presence in cocoa and its derivatives was reported at the sixth meeting of the Committee on Food Contaminants in 2012 and added to the list of contaminants and natural toxicants present in food (FAO/OMS, 2014). Therefore, starting in 2019, the European Union (EU) implements the standard and maximum permissible limits of $\mathrm{Cd}$ in cocoa and its derivatives.
The maximum standard limit for $\mathrm{Cd}$ in cocoa varies by norm and country. The EU legislated the maximum permissible levels in food products in regulation $D O L$ 364 of $12 / 20 / 2006$, p. 5, and established a permissible range between 0.2 and $0.5 \mathrm{mg} \mathrm{kg}{ }^{-1}$ for $\mathrm{Cd}$ in powdered cocoa and chocolate products. García and Dorronsoro (2002) reported maximum levels in cocoa beans of $0.50 \mathrm{mg} \mathrm{kg}$, which would meet the EU and the international market's requirements.

Cd can bioaccumulate and persist but not biodegrade, and it is a precursor of various cancers, oxidative stress, inflammation, and tissue injury in humans (Das \& Al-Naemi, 2019; Londoño-Franco, Londoño-Muñoz \& Muñoz-García, 2016). In Japan, Itai-Itai syndrome, caused by consuming rice contaminated with Cd (Salama, 2018; Clemens, Aarts, Thomine \& Verbruggen, 20I3; Jiménez, 2015), revealed the risk of human contamination from cocoa and vegetable intake. $\mathrm{Cd}$ is distributed in the Earth's crust at a mean concentration of $0.1 \mathrm{mg} \mathrm{kg}$; in rocks, it does not exceed 
$0.3 \mathrm{mg} \mathrm{kg}^{-1}$, and it has been found in limestone (Ramtahal et al. 2018; Wang et al. 2015). Cd contamination is associated with anthropogenic actions (Bravo \& Benavides, 2020). Caviedes, Muñoz, Perdomo, Rodríguez, \& Sandoval (2015), and Arévalo-Gardini et al. (2016) reported that irrigation waters from solid waste treatment systems are sources of $\mathrm{Cd}$ and other metals. Roberts (2014) reported that phosphorus fertilizers contain Cd; Alloway (2013) identified a close relationship between heavy metals and specific sources of fertilizers and pesticides and argued that this situation is exacerbated when species that absorb $\mathrm{Cd}$ are cultivated. On the other hand, high spatial variability in soil Cd contents is recognized, making it necessary to develop projects that seek their quantification, persistence, and speciation (Bravo \& Benavides, 2020; Caviedes et al. 2015).

Cd is toxic to some species, and its specific entry mechanisms are unknown, although proteins are involved (Huamaní-Yupanqui, Huauya-Rojas, Mansilla-Minaya, FloridaRofner, \& Neira-Trujillo, 20I2). Some species accumulate $\mathrm{Cd}$, including barley (Hordeum vulgare), corn (Zea mays) (González \& Lobo, 2013), alfalfa (Medicago sativa) (LaraViveros et al. 2015), rice (Oryza sativa) (Chaney, 2012), T. cacao L. (Ramtahal et al., 20I5), and some tree species (Callegario-Pereira, Dormelas-Rodrigues, Soares-dos Santos, do Nascimento-Guedes, \& do Amaral-Sobrinho, 20I2). In addition to generating risk to human and animal health, $\mathrm{Cd}$ contents can severely affect the agricultural export products such as cocoa, with demand in North American and European markets, where exists standard norms that prevent its reception if their content exceeds certain limits (García and Dorronosoro, 2002). The Cd accumulation process is of particular interest in cocoa farms in Colombia because there are producing areas with a high $\mathrm{Cd}$ content that could dangerously join the food chain and thus, affect human health. Therefore, it is of vital interest to know the soil $\mathrm{Cd}$ contents and determine if it moves to plant and, once inside it, establish if it is accumulating mainly in the organs destined for food (Lara-Viveros et al. 2015).

Therefore, areas are required where new cocoa plantations can be sown for export purposes. It is necessary to know the soil Cd contents and predict if it moves towards the plants and accumulates in the grain, and given the lack of information on whether cocoa (T. cacao L.) grown in northern Colombia absorbs $\mathrm{Cd}$, we evaluated its presence in the soil, absorption, and accumulation in plant tissues.

\section{Methodology}

Location

This study was conducted in the department of Magdalena, Colombia, at the geographic coordinates $10^{\circ} 46^{\prime} 00^{\prime \prime} \mathrm{N}$ and 300 dry forest, and the climate is warm and dry, with a mean annual temperature of $27^{\circ} \mathrm{C}$ and relative humidity of $82 \%$ (Piraneque, Aguirre, \& Reis, 2018). Plant material and soil samples were collected in 20 georeferenced agricultural plots distributed in the Sierra Nevada of Santa Marta (zone I) and the Banana Zone (zone 2) (Figure I).

\section{Soils characteristics}

Soils in zone I were classified as Entic Haplustolls originating from granodiorite, quartz diorite, and granite. These are deep, well-drained soils with loam to sandy-loam texture; they are moderately acidic to neutral $(\mathrm{pH} 6.3$ to 7.7$)$ with moderate to high natural fertility due to low organic matter content and cation exchange capacity. These soils contain kaolinite (50\%), micas (5-30\%), montmorillonite (30-50\%) and, vermiculite $(5-30 \%)$ in the clay fraction and quartz (5$15 \%)$, feldspar (5-15\%), and interstratified trace minerals in the sand fraction (Aguirre, Piraneque, \& Vásquez, 2015; IGAC, 2009).

Soils in zone 2 were classified as Typic Ustorthens originating from gneiss and schists. These are relatively deep, well-drained soils with sandy texture; they are neutral to slightly acidic with moderate natural fertility due to medium organic matter content and high cation exchange capacity. These soils contain non crystalline material, kaolinite $(40 \%)$, gypsite $(30-50 \%)$ and, vermiculite $(5-30 \%)$ in the clay fraction and quartz (22-26\%), feldspar (36-38\%), and hornblende $(20-22 \%)$ in the sand fraction (Aguirre, Piraneque, \& Vásquez, 2015; IGAC, 2009).

\section{Plant material, sampling and establishment}

Different cocoa varieties are grown in small cultivated plots, but the product is recognized in the international market for its aroma and provides economic sustenance for indigenous people and farmers. The plots have the added value of proximity to the seaport, which is a determinant of cocoa export. Using a transect, 20 agricultural plots were selected with productive plants older than eight years from which cocoa leaves (healthy and functional from the central portion of the branches in the middle third of the crown) and fruits were collected. The plant material was transported to the Soil Laboratory of the University of Magdalena, were it was washed with distilled water and dried at room temperature; the beans were separated from the fruit or pod (shell), and the material was dried at $70^{\circ} \mathrm{C}$ for 48 hours, ground, packed and labeled.

\section{Soil sampling and determinations}

Soil samples $(\mathrm{I} \mathrm{kg})$ were randomly collected for analysis from the 20 cocoa farms at two depths $(0-10$ and $10-20 \mathrm{~cm})$ per 

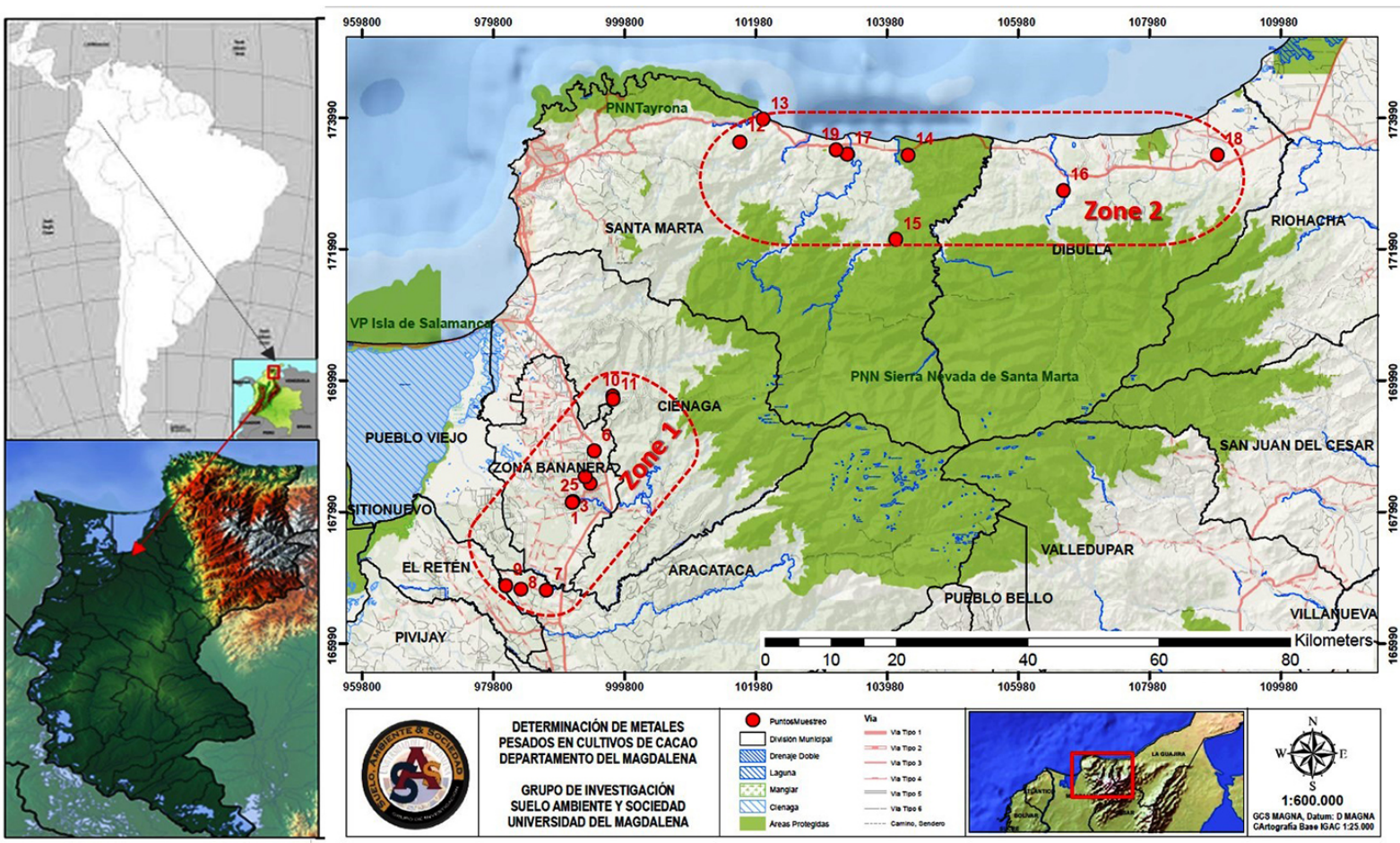

Figure I. Location of the agricultural plots and sampling zones where Cd content in the cocoa tissues and soils cultivated with cocoa was identified.

Source: Authors

plot. The samples were air-dried, then, were sieved through a 2-mm mesh, packed in plastic bags, and tightly sealed (Figure 2).

The tissue and soil samples were taken to the laboratory of the International Center for Tropical Agriculture (CIAT) in Palmira for analysis, where the respective determinations were made per methods described in Table I.

\section{Statistical analysis}

The parameters obtained from the chemical determinations (plant tissue and soil) were subjected to analysis of variance and Tukey's post hoc test $(p<0.05)$. The results that differed were subjected to Pearson's correlation analysis between the heavy metal content in the plant tissue and soil properties. Statistical analyses were conducted using $R$ software v. 3.02 (R Development Core Team 2015, available at www.r-project.org).

\section{Results}

\section{Heavy metals in plant tissues}

The mean $\mathrm{Cd}, \mathrm{Ni}, \mathrm{Pb}, \mathrm{Cr}, \mathrm{Ca}, \mathrm{Mg}$ and $\mathrm{K}$ content in the beans, shells and leaves of T. cacao grown in the study area are shown in Appendix I. The beans from zone I had a mean
Cd content of $0.51 \mathrm{mg} \mathrm{kg} \mathrm{g}^{-1}$, whereas the beans from zone 2 had a mean of $0.66 \mathrm{mg} \mathrm{kg}$. These values exceeded the maximum permissible limit $\left(0.5 \mathrm{mg} \mathrm{kg}^{-1}\right)$ reported by García and Dorronsoro (2002). The beans from plot 3 of zone I had a Cd content of $0.96 \mathrm{mg} \mathrm{kg}$, and those from plots I7, II and 15 of zone 2 had Cd contents of $1.25 \mathrm{mg} \mathrm{kg}$, $1.08 \mathrm{mg} \mathrm{kg}^{-1}$ and $0.86 \mathrm{mg} \mathrm{kg}^{-1}$, respectively. These values are considered unsafe for direct consumption. In contrast, plots 6 and 16 had the lowest $C d$ contents, with $0.21 \mathrm{mg} \mathrm{kg}^{-1}$ and $0.15 \mathrm{mg} \mathrm{kg}^{-1}$, respectively (Figure 3 ).

The mean $\mathrm{Cd}$ content in the leaves did not differ significantly across the analyzed samples, with means of $0.43 \mathrm{mg} \mathrm{kg}^{-1}$ in zone $\mathrm{I}$ and $0.4 \mathrm{l} \mathrm{mg} \mathrm{kg}{ }^{-1}$ in zone 2 . The highest $\mathrm{Cd}$ content was reported in plot 6 , at $0.8 \mathrm{I} \mathrm{mg} \mathrm{kg}^{-1}$, and in plot $\mathrm{II}$, at $1.24 \mathrm{mg} \mathrm{kg}^{-1}$.

The $\mathrm{Cd}$ content in the shells was heterogeneous, but without significant differences. The mean values were 0.50 $\mathrm{mg} \mathrm{kg}^{-1}$ in zone $\mathrm{I}$ and $0.40 \mathrm{mg} \mathrm{kg}^{-1}$ in zone 2. These values were lower than those reported by INIAP-PROMSA (2003) in Ecuador, where a mean of $1.08 \mathrm{mg} \mathrm{kg}^{-1} \mathrm{Cd}$ was recorded in the shells.

The values reported for the shells and leaves generally did not exceed the permissible limits; however, more $\mathrm{Cd}$ had accumulated in the beans, with $0.5 \mathrm{I}$ and $0.67 \mathrm{mg} \mathrm{kg}^{-1}$ for 


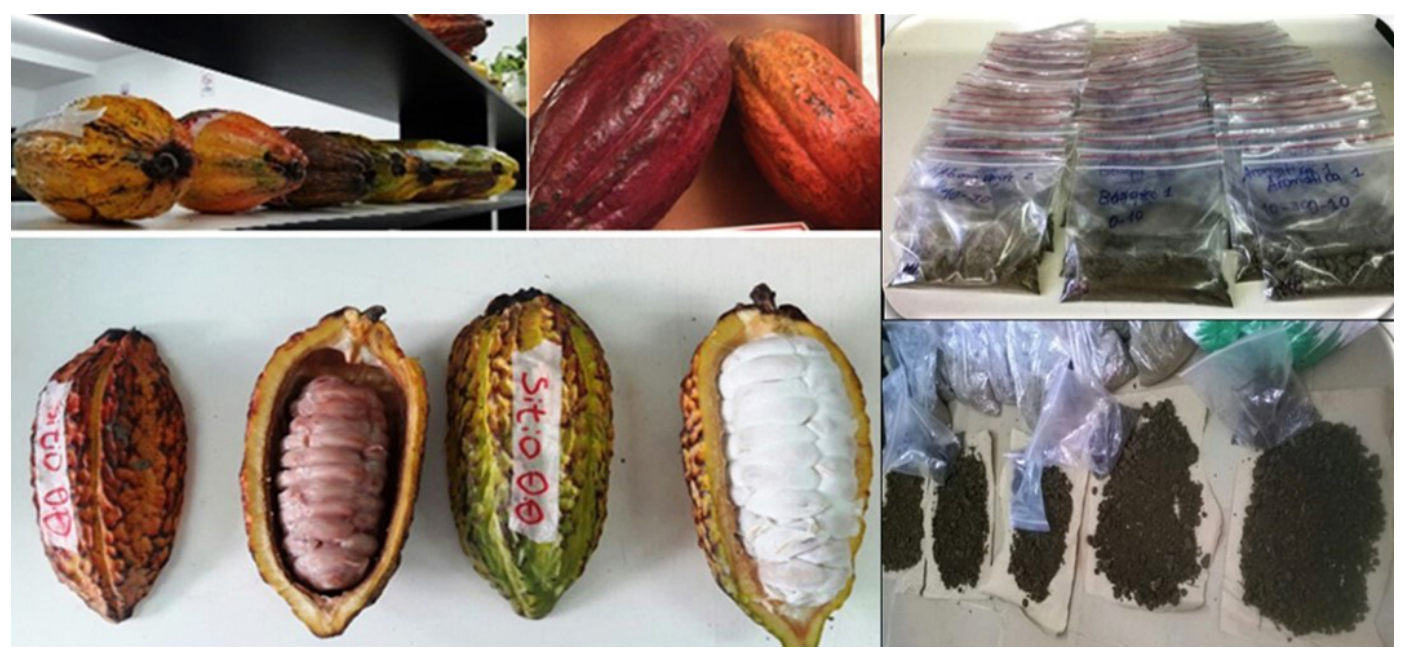

Figure 2. Cocoa pods and soil samples were collected in cocoa-producing areas in northern Colombia to determine the heavy metal content.

Source: Authors

Table I.

Laboratory methods used to determine the heavy metal content in cocoa tissue samples from cocoa-producing areas in northern Colombia.

\begin{tabular}{|c|c|c|}
\hline Variable & Method & Reference \\
\hline $\mathrm{pH}$ & Potentiometric - soil: water ratio of $1: 1$ & Jackson (2005) \\
\hline Organic matter & Walkley and Black method & \\
\hline $\begin{array}{l}\text { Total } \mathrm{Cd}, \mathrm{Ni}, \mathrm{Pd} \text { and } \mathrm{Zn} \text { in the } \\
\text { tissues }\end{array}$ & $\begin{array}{l}\text { Regal water }\left(\mathrm{HCl} \mathrm{HNO}_{3}-3: 1\right) \text {, Quantification by atomic absorption } \\
\text { spectrometry }\end{array}$ & NTC 3888, ISO 11466: 1964 \\
\hline $\mathrm{Ca}, \mathrm{Mg}$ and $\mathrm{K}$ & $\begin{array}{l}\text { Soils with } \mathrm{pH} \leq 5.5 \text { by } 1 \mathrm{M} \text { ammonium acetate and soils with } \mathrm{pH}>5.5 \text { by } 1 \\
\mathrm{~N} \mathrm{KCl} \text { and determined by atomic absorption spectrophotometry }\end{array}$ & Anderson and Ingram (1993) \\
\hline $\begin{array}{l}\text { Total } \mathrm{Cd} \mathrm{Ni}, \mathrm{Pb}, \mathrm{Fe}, \mathrm{Cr} \text { and } \\
\mathrm{Zn} \text { in the soils }\end{array}$ & $\begin{array}{l}\text { Extraction with diethylenetriamine pentaacetate (DTPA) and quantification } \\
\text { by atomic absorption EPA-3050B }\end{array}$ & US EPA (1996) \\
\hline
\end{tabular}
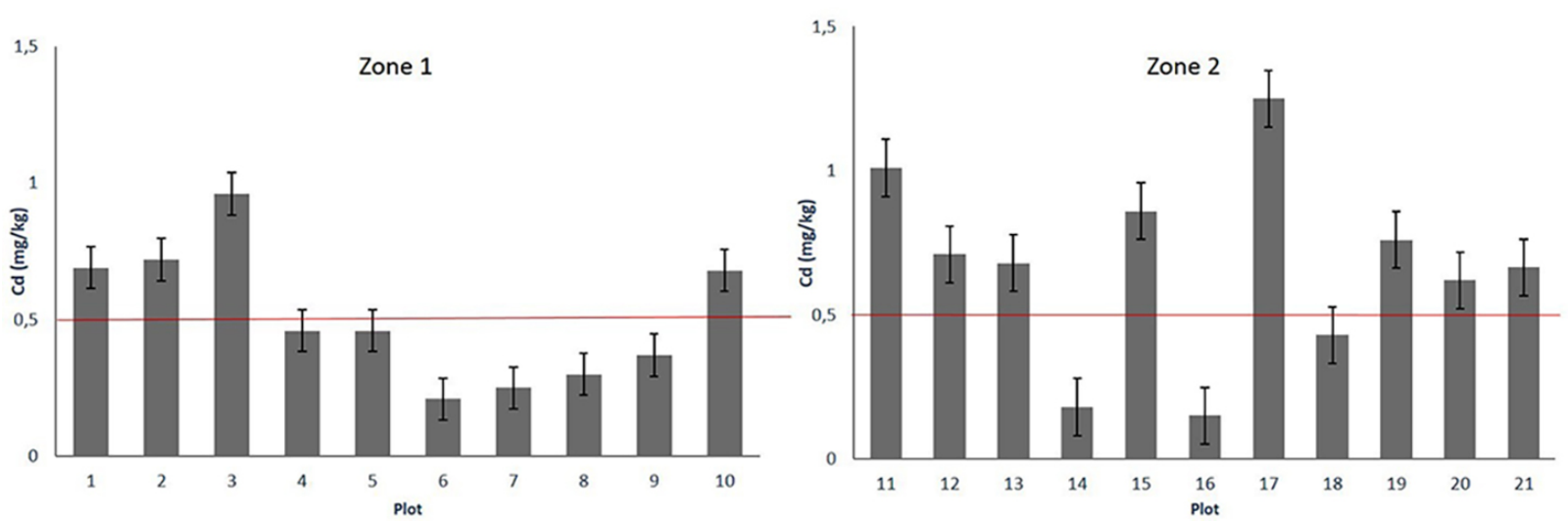

Figure 3. Total $\mathrm{Cd}$ content in cocoa beans from cocoa-producing areas. Source: Authors

Legend: __ Reference level from García and Dorronsoro (2002) 
zones I and 2, respectively, demonstrating Cd mobility in the plant. Miranda et al. (2008) state that the Cd present in leaf tissue is linked to specific physiological stages and is involved in diverse metabolic pathways.

\section{Heavy metals in soils}

Table 2 shows the soil analysis results, in which the $\mathrm{pH}$ ranged from 5.7 to 6.07 , with no significant differences among sites or between zones. The $\mathrm{Fe}$ and $\mathrm{Mn}$ levels were optimal ( 10 to $50 \mathrm{mg} \mathrm{kg}^{-1}$ ), and the $\mathrm{Zn}$ level was adequate in some sites but deficient in others. The $\mathrm{Ca}^{+2}$ content ranged from intermediate $\left(3.0 \mathrm{cmol}+\mathrm{kg}^{-1}\right)$ to high $\left(\geq 6.0 \mathrm{cmol}+\mathrm{kg}^{-}\right.$ '), the $\mathrm{Mg}$ content was intermediate ( 1.5 to $\mathrm{I}, 7 \mathrm{cmol}+\mathrm{kg}^{-}$ '), and $\mathrm{K}$ was deficient $\left(<0.2 \mathrm{cmol}+\mathrm{kg}^{-1}\right)$. For this reason, the $\mathrm{Ca} / \mathrm{K}$ and $(\mathrm{Ca}+\mathrm{Mg}) / \mathrm{K}$ cation ratios were analyzed, which confirmed that $K$ deficiency may be induced. The percentage of organic matter was low. Regarding the total metal concentrations in the soil, no evidence of $\mathrm{Cd}, \mathrm{Pb}, \mathrm{Ni}$ or $\mathrm{Cr}$ contamination was found. Concentrations were not reported from some sites because the values were lower than the method's limit of quantification (< LOQ).

The mean heavy metal content in the analyzed soils did not exceed the maximum concentrations established by García and Dorronsoro (2002). In zone I, the Cd concentration ranged from $0.19 \mathrm{mg} \mathrm{kg}^{-1}$ at $10 \mathrm{~cm}$ deep to $0.02 \mathrm{mg} \mathrm{kg}^{-1}$ at $20 \mathrm{~cm}$ deep. A similar pattern was observed in zone 2, consistent with the studies of Mite, Carrillo, \& Durango (2010) and Gramlich et al. (2018), who reported surface $\mathrm{Cd}$ accumulation. Heavy metal adsorption is strongly conditioned by $\mathrm{pH}$ (and thus its solubility) and the organic matter content, clay, oxides and hydroxides in the soil (Olivares-Rieumont et al., 20I3).

Bioavailability is associated with soil concentration and plant species. Pearson correlation analysis between $\mathrm{Cd}, \mathrm{Pb}$, $\mathrm{Ni}$ and $\mathrm{Cr}$ content in the soil with foliar variables (bean, leaf and shell content) indicated an association between the heavy metal concentrations in the soil and foliar contents (Table 3).

The soil Cd content correlated positively with the plant $\mathrm{Cd}$ content as well as with $\mathrm{Ca}$ concentrations in the soil. However, it was inversely proportional to the plant's $\mathrm{Ca}$ content, while the plant's Cd content was inversely proportional to the $\mathrm{Ca}$ and $\mathrm{K}$ uptake.

\section{Association between variables}

The results showed that the soil $\mathrm{Ni}$ concentration was affected by that of soil $\mathrm{Cr}$ and is inversely proportional to

Table 2.

Results of the soil analysis by cocoa-producing zone in northern Colombia.

\begin{tabular}{|c|c|c|c|c|c|}
\hline \multirow[b]{3}{*}{ Depth } & & \multicolumn{4}{|c|}{ ZONE } \\
\hline & & \multicolumn{2}{|c|}{ A } & \multicolumn{2}{|c|}{ B } \\
\hline & & 1 & 2 & 1 & 2 \\
\hline $\mathrm{pH}$ & Un & 5.78 & 5.81 & 6.07 & 5.77 \\
\hline Cox & $\%$ & 1.16 & 0.72 & 1.06 & 0.66 \\
\hline MO & $\%$ & 2.36 & 1.63 & 2.41 & 1.50 \\
\hline$P$ & $\mathrm{mg} \mathrm{kg}^{-1}$ & 37.30 & 40.38 & 24.56 & 15.47 \\
\hline $\mathrm{Ca}$ & $\mathrm{cmol} \mathrm{kg}^{-1}$ & 6.00 & 5.53 & 5.58 & 4.74 \\
\hline $\mathrm{Mg}$ & $\mathrm{cmol} \mathrm{kg}^{-1}$ & 1.56 & 1.50 & 1.69 & 1.60 \\
\hline $\mathrm{K}$ & $\mathrm{cmol} \mathrm{kg}^{-1}$ & 0.10 & 0.09 & 0.21 & 0.18 \\
\hline $\mathrm{Fe}$ & $\mathrm{mg} \mathrm{kg}^{-1}$ & 21.62 & 29.07 & 18.37 & 17.81 \\
\hline $\mathrm{Mn}$ & $\mathrm{mg} \mathrm{kg}^{-1}$ & 16.07 & 14.78 & 28.60 & 22.25 \\
\hline $\mathrm{Zn}$ & $\mathrm{mg} \mathrm{kg}^{-1}$ & 1.95 & 2.21 & 3.20 & 1.38 \\
\hline $\mathrm{Cd}$ & $\mathrm{mg} \mathrm{kg}^{-1}$ & 0.02 & 0.00 & 0.00 & 0.00 \\
\hline $\mathrm{Pb}$ & $\mathrm{mg} \mathrm{kg}^{-1}$ & 0.57 & 0.47 & 6.80 & 2.78 \\
\hline $\mathrm{Ni}$ & $\mathrm{mg} \mathrm{kg}^{-1}$ & 18.15 & 14.98 & 11.60 & 20.13 \\
\hline $\mathrm{Cr}$ & $\mathrm{mg} \mathrm{kg}^{-1}$ & 39.97 & 31.80 & 20.60 & 29.80 \\
\hline
\end{tabular}

Depth: I = 0-10 cm, 2 = 10-20 cm; Cd, Pb, Ni and $\mathrm{Cr}$ concentrations were determined by inductively coupled plasma mass spectrometry at the CIAT Laboratory.

Source: Authors 
Table 3.

Pearson correlation between the $\mathrm{Cd}, \mathrm{Pb}, \mathrm{Ni}$ and $\mathrm{Cr}$ content available in the soil and their relationship to other nutrients.

\begin{tabular}{|c|c|c|c|c|c|c|c|c|c|c|c|}
\hline Metal & Ca-p & K-p & Cd-p & Cr-p & Ca-s & Mg-s & K-s & Fe-s & Ni-s & Cr-s & $\mathrm{pH}$ \\
\hline $\mathrm{Pb}-\mathrm{s}$ & & & & & & 0.51 & 0.75 & -0.39 & & & \\
\hline Cd-s & -0.4 & & 0.3 & & 0.34 & & & & & 0.02 & \\
\hline Cd-f & -0.29 & -0.39 & & & & & & & & & \\
\hline $\mathrm{Ni}-\mathrm{s}$ & & & & & & & & & & 0.412 & -0.37 \\
\hline $\mathrm{Ni}-\mathrm{f}$ & -0.59 & & & & & & & & & & \\
\hline $\mathrm{Cr}-\mathrm{s}$ & & & & 0.41 & & & & & & & -0.37 \\
\hline $\mathrm{Cr}-\mathrm{f}$ & & & & & & & & & 0.62 & & \\
\hline
\end{tabular}

the foliar $\mathrm{Ca}$ content as well as the $\mathrm{pH}$. Although $\mathrm{Cr}$ poses no toxicological risk, it was positively correlated with the $\mathrm{Ni}$ content in the soil and is affected by the $\mathrm{pH}$. Ni and $\mathrm{Cr}$ in the soil were inversely correlated with the $\mathrm{pH}$, indicating that this parameter directly affects their solubility.

Figure 4 shows the association between the studied variables regarding the heavy metal concentrations in the cocoa crop in the cocoa-producing areas of northern Colombia. Larger balls indicate greater association, blue represents positive associations, and red represents inverse relationships, which confirm the previous analysis.

\section{Discussion}

\section{Heavy metals in plant tissues}

Chávez et al. (2015) reported Cd values of 0.02 to $3 \mathrm{mg}$ $\mathrm{kg}^{-1}$ in cocoa beans in southern Ecuador. Gramlich et al. (2018) recorded $\mathrm{Cd}$ levels higher than $1.1 \mathrm{mg} \mathrm{kg}^{-1}$ in beans from Honduras. Huamaní-Yupanqui et al. (2012) reported a mean Cd content of $1.55 \mathrm{mg} \mathrm{kg-}{ }^{-}$in cocoa beans from the province of Leoncio Prado in Peru, and Martínez and Palacio (2010) found $\mathrm{Cd}$ content ranging from 4 to $7 \mathrm{mg} \mathrm{kg}^{-1}$ in San Vicente de Chucurí, Santander department, Colombia. These concentrations were higher than those found in the present study area.

Nevertheless, the results of the Cd analysis for the cocoa beans of some plots exceeded the maximum value cited by García and Dorronsoro (2002) and therefore, the value allowed by Lanza, Churión, Liendo, \& López (2016) and the EU. This finding suggests the need to further investigate Cd's origin to build a distribution map and monitor concentrations in the beans by zone.

The lowest leaf $\mathrm{Cd}$ content was observed in plot 17, at 304 $0.20 \mathrm{mg} \mathrm{kg}^{-1}$, but in this plot, the Cd content of the beans was relatively high, indicating $\mathrm{Cd}$ mobility in the plant. This finding agrees with the report by Caunii et al. (20I5), who cautioned about $\mathrm{Cd}$ mobility in leaves and considered the maximum tolerable $\mathrm{Cd}$ content to be $0.5 \mathrm{mg} \mathrm{kg}^{-1}$.

Finally, the values reported for the shells and leaves generally did not exceed the permissible limits; however, more Cd had accumulated in the beans, with $0.5 \mathrm{I}$ and $0.67 \mathrm{mg} \mathrm{kg}^{-1}$ for zones I and 2, respectively, demonstrating Cd mobility in the plant. Miranda et al. (2008) state that the Cd present in leaf tissue is linked to specific physiological stages and is involved in diverse metabolic pathways. Likewise, Pernía, De Sousa, Reyes, \& Castrillo (2008) reported that Cd uptake by the roots reflects its concentration and availability in the soil.

\section{Heavy metals in soils}

Regarding the total metal concentrations in the soil, no evidence of $\mathrm{Cd}, \mathrm{Pb}, \mathrm{Ni}$ or $\mathrm{Cr}$ contamination was found. Concentrations were not reported from some sites because the values were lower than the method's limit of quantification (<LOQ). Thus, the mean heavy metal content in the analyzed soils did not exceed the maximum concentrations established by García and Dorronsoro (2002). In zone I, the $\mathrm{Cd}$ concentration ranged from 0.19 $\mathrm{mg} \mathrm{kg}-1$ at $10 \mathrm{~cm}$ deep to $0.02 \mathrm{mg} \mathrm{kg}^{-1}$ at $20 \mathrm{~cm}$ deep. A similar pattern was observed in zone 2 , consistent with the studies of Mite, Carrillo, \& Durango (2010) and Gramlich et al. (2018), who reported surface $C d$ accumulation and that Heavy metal adsorption is strongly conditioned by $\mathrm{pH}$ (and thus its solubility) and the organic matter content, clay, oxides, and hydroxides in the soil (Olivares-Rieumont et al., 2013).

Although Roberts (2014) reported that applied phosphorus fertilizers (phosphate rock) are a source of Cd contamination in agricultural land and constitute more than $50 \%$ of the $\mathrm{Cd}$ 


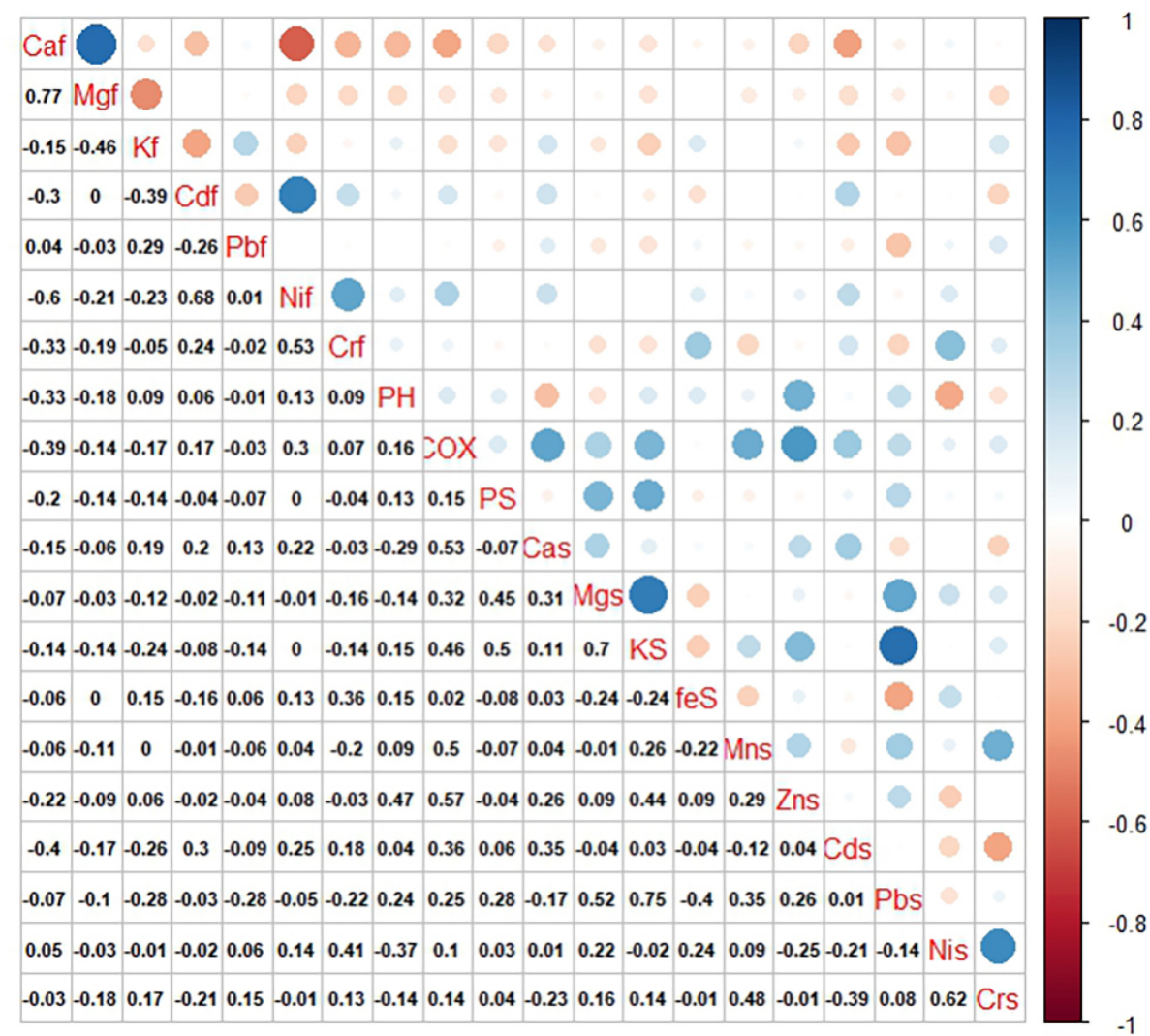

Figure 4. Associations between the variables measured in the soil and aerial organs of cocoa plants grown in northern Colombia. Blue circle $=$ positive associations, and red circle $=$ inverse relationships .

Source: Authors

that enters into the soil (this hypothesis is not tested here). However, given its extensive use, phosphate rock may be a possible contamination route for $\mathrm{Cd}$ in this area, further studies with more focus on fertilizers, are suggested in the north of Colombia.

The solubility and availability of metals in soils is affected by the interactions between $\mathrm{pH}$, cation exchange capacity (CEC), precipitation, complexation and chelation. In this regard, Silveira et al. (2003) reported that when metals adsorb to soil particles, their concentration in the solution is reduced; thus, the metals cannot be quantified therefore, soils with high CECs have more exchange sites available in the colloidal fraction for adsorption and possible immobilization. Likewise, Contreras, Herrera and Izquierdo (2005) identified that soil $\mathrm{Ca}$ is found both as free $\mathrm{Ca}$ and as carbonate and calcium phosphate; therefore, $\mathrm{Cd}$ can be controlled by alkalization and precipitated.

Further research is required to assess the risk of $\mathrm{Cd}$ soil contamination, and regular monitoring of heavy metals should be carried out to evaluate the existence of any potential threat to food safety. For this, it is necessary to advance in new detection techniques such as the use of two-dimensional electrical resistivity tomography described by Bravo and Benavides (2020) or application of organic amendments like biochar for reducing the soil $\mathrm{Cd}$ movement and Cd plant uptake reported by $\mathrm{Cui}$ et al. (201I), which promotes the soil quality, soil health, as well as food security.

\section{Association between variables}

Regarding the $\mathrm{Ca}$ and $\mathrm{Cd}$ association, Cui et al. (20II) and Solti et al. (201I) mentioned that high Ca concentrations in soils can reduce $\mathrm{Cd}$ uptake because ionic competition occurs between these elements, thus reducing their uptake. Likewise, Solti et al. (20II) reported that Cd entering the roots directly competes with $\mathrm{Ca}, \mathrm{K}, \mathrm{Fe}$ and $\mathrm{Cu}$ because the same transporter proteins carry out $\mathrm{Cd}$ absorption. Huamaní-Yupanqui et al. (2012) explained that for $\mathrm{Cd}$ to precipitate, it must have affinity for carbonates or phosphates, even if $\mathrm{pH}$ is slightly acidic.

The solubility and availability of metals in soils is affected by the interactions between $\mathrm{pH}$, cation exchange capacity 
(CEC), precipitation, complexation and chelation. Soils with high CECs have more exchange sites available in the colloidal fraction for adsorption and possible immobilization. Likewise, as the soil $\mathrm{Ca}$ is found either in free form or as carbonate and calcium phosphate, therefore, $\mathrm{Cd}$ can be controlled by alkalization and precipitated (OlivaresRieumont et al., 2013).

Carbonate presence in the study soils was not analyzed, but the study area's geological characteristics and proximity to the sea indicate that carbonate may have been present; thus, insoluble $\mathrm{Cu}, \mathrm{Zn}$ and $\mathrm{Cd}$ compounds can form and be adsorbed by carbonates, and $\mathrm{Ca}$ and $\mathrm{Cd}$ in the soil may remain adhered and undetectable this is an essential issue for future research. So, the fact that soil $\mathrm{Ni}$ and $\mathrm{Cr}$ correlated inversely with $\mathrm{pH}$, is consistent with that reported by Chávez et al. (2015), who reported that low redox potential increases heavy metal solubility, and with the Agency for Toxic Substances \& Disease Registry (ATSRD, 2012), which maintains that $\mathrm{Ni}$ is immobile in alkaline soils and precipitates in the form of carbonates and insoluble phosphates. This is important to select new areas for the cocoa crop.

The foliar calcium content was associated with most of the variables studied and was inversely proportional to $\mathrm{Cd}, \mathrm{Ni}$, $\mathrm{Pb}$ and $\mathrm{Cr}$ uptake. If $\mathrm{Ca}$ uptake is increased, cocoa metal uptake may decrease. Although the calcium concentration in the soil is in the intermediate range, increasing it would be beneficial without neglecting the cationic relationships. Further research should focus on the application of soluble $\mathrm{Ca}$ effect on cocoa Cd uptake growing in northern Colombia.

\section{Conclusions}

The results of this study lead to the following conclusions regarding the heavy metals content in soils and cocoa tissues in northern Colombia:

- The cadmium concentration in the cocoa beans fluctuated between zones and plots, but the values all exceed the permissible limit for this element in cocoa beans $\left(0.5 \mathrm{mg} \mathrm{kg}^{-1}\right)$, indicating that the grains are contaminated. However, the soil Cd concentration shows that soil is optimal for cocoa cultivation, which suggests that the $\mathrm{Cd}$ origin is anthropogenic and related to crop management. Still, the correlation with other plant nutrients suggests that soil carbonates or organic amendments can reduce $\mathrm{Cd}$ uptake.

- These results serve as a reference point for future research about heavy metals presence on cocoa, with
$\mathrm{Cd}$ and plant $\mathrm{Cd}$ contents, to evaluate the risk for food safety. For this, currently, techniques with promising efficiencies are being developed to reduce energy and operating costs during the sampling stage, allowing for their implementation and sustainability.

\section{Conflict of interest}

The authors have no conflicts of interest to declare.

\section{References}

I. Agency for Toxic Substances \& Disease Registry (ATSDR). Public Health Statement for Cadmium. 2012. http://www.atsdr.cdc.gov/ toxprofiles $/$ tp.asp?id $=48 \&$ tid $=15$

2. AGUIRRE, Sonia Esperanza; PIRANEQUE, Nelson Virgilio;VÁSQUEZ, José Rafael. Relationship between the nutritional status of banana plants and black sigatoka severity in the Magdalena region of Colombia. In: Agronomía Colombiana. 2015. vol. 33, no. 3, p. 348-355. https://doi.org/10.15446/agron.colomb.v33n3.51900

3. ALLOWAY, Brian. Heavy Metals in Soils, Trace Metals and Metalloids in Soils and their Bioavailability (3ra Ed.) United Kingdom 2013.597 p.

4. ANDERSON, Jonathan Michael; INGRAM, Jhon. S. I. Tropical soil biological and fertility: a handbook of methods. Wallingford: CAB International, 2ed., 1993. 221p. https://doi.org/10.1017/ S00I44797000024832

5. ARÉVALO-GARDINI, Enrique; OBANDO-Cerpa, Meyier E.; ZÚÑIGA-CERNADES, Luis B.; ARÉVALO-HERNÁNDEZ, Cesar O.; BALIGAR, Viripax; HE, Zhenli. Metales pesados en suelos de plantaciones de cacao (Theobroma cacao L.) en tres regiones del Perú. In: Ecología Aplicada. 2016. vol. 15, no. 2, p. 8I-89. https://doi. org/l0.21704/rea.v15i2.747

6. BRAVO, Daniel; BENAVIDES, Javier. The Use of a Two-Dimensional Electrical Resistivity Tomography (2D-ERT) as a Technique for Cadmium Determination in Cacao Crop Soils. In Applied sciences. 2020. vol.10, no. I2, 4 I49. https://doi.org//0.3390/app I0124I49

7. CALLEGARIO-PEREIRA, Ana C.; DORMELAS-RODRIGUES, Ana C.; SOARES-Dos SANTOS, Fabiana; Do NASCIMENTO GUEDES, Jair; Do AMARAL-SOBRINHO, Nelson. Concentração de metais pesados em espécies arbóreas utilizadas para revegetação de área contaminada. In: Revista Ciência Agronômica. 2012. vol. 43 no. 4, p. 64I-647. https://doi.org/I0.1590/SI806-669020I2000400004

8. CAUNII, Angela; NEGREA, Adina; PENTEA, Marius; SAMFIRA, lonel., MOTOC, Marilena; BUTNARIU, Monica. Mobility of heavy metals from soil in the two species of the aromatic plants. In: Revista de Chimie. 2015. Vol. 66, no. 3, p. 382-386. http://orcid.org/0000-00022032-5000

9. CAVIEDES RUBIO, Diego Iván; MUÑOZ CALDERÓN, Ramiro Adolfo; PERDOMO GUALTERO, Alexandra; RODRIGUEZ ACOSTA, 
Daniel;SANDOVAL ROJAS, Ivan Javier.Tratamientos para la remoción de metales pesados comúnmente presentes en aguas residuales industriales. Una revisión. In: Ingeniería y Región. 2015. vol. I3, no I, p. 73-90. https://dialnet.unirioja.es/descarga/articulo/5432290.pdf

10. CHANEY, Rufus. Food safety issues for mineral and organic fertilizers. In: Advances in Agronomy. 2012. vol. 117, p. 51-116. https://doi. org//0.1016/B978-0-12-394278-4.00002-7

II. CHÁVEZ, Eduardo; HE, Zhenli; STOFFELLA, Peter Joseph; MYLAVARAPU, Rao; Li, Yuncong; MOYANO, Byron; BALIGAR, Virupax. Concentration of cadmium in cacao beans and its relationship with soil cadmium in southern Ecuador. In: Science of the Total Environment. 2015. vol. 533, p. 205-214. https://doi.org/10.1016/j. scitotenv.2015.06.106

12. CLEMENS, Stephan; AARTS, Mark G.; THOMINE, Sébastien; VERBRUGGEN, Nathalie. Plant science: the key to preventing slow cadmium poisoning. In: Trends Plant Sci. 2013. vol. 18, no. 2, p. 93-99. https://doi.org//0.1016/j.tplants.2012.08.003

13. CONTRERAS, Francisco; HERRERA, Teodoro; IZQUIERDO, Alexis. Efecto de dos fuentes de carbonato de calcio $(\mathrm{CaCO})$ sobre la disponibilidad de cadmio para plantas de cacao Theobroma cacao L.) en suelos de Barlovento, estado Miranda. Venesuelos. 2005. Vol. 13, no. I, p. 52 - 63. http://190.169.30.98/ojs/index.php/rev_venes/article/ view/979/908

14. CUI, Liqiang; LI, Lianqing; ZHANG, Afeng; PAN, Genxing; BAO, Dandan; CHANG, Andrew. Biochar amendment greatly reduces rice Cd uptake in a contaminated paddy soil: a two-year field experiment. In: BioResources. 20I I. vol. 6, no. 3, p. 2605-2618. https://ojs.cnr.ncsu. edu/index.php/BioRes/article/download/BioRes_06_3_2605_Cui LZPBC Biochar Amendment Rice Cd Uptake/ 1023

15. DAS, Sandra Concepción; AL-NAEMI, Hamda A. Cadmium Toxicity: Oxidative Stress, Inflammation and Tissue Injury. In: Occupational Diseases and Environmental Medicine. 2019. Vol. 7, no. 4, p. I44-I63. https://doi.org//0.4236/odem.2019.74012

16. FAO/OMS. Programa Conjunto de cacao y derivados. Normas Alimentarias Comité Del Codex Sobre Contaminantes de Los Alimentos Novena reunión Nueva Delhi, India. Anteproyecto De Niveles Máximos Para El Cadmio En El Chocolate y Productos. 2014. http://www.fao.org/tempref/codex/Meetings/CCCF/cccf9/cf09_06s. pdf

17. GARCÍA, Ines; DORRONSORO, Carlos. Contaminación por metales pesados. Retrieved on April 25 (2002). http://www.edafologia.net/ conta/temal $5 /$ fact.htm

18. GONZÁLEZ, Águeda; LOBO, Carmen. Growth of four varieties of barley (Hordeum vulgare L.) in soils contaminated with heavy metals and their effects on some physiological traits. In: American Journal of Plant Sciences. 2013. vol. 4, p. 1799-1810. https://doi.org//0.4236/ ajps.2013.49221

19. GRAMLICH, Anja; TANDY, Susan., GAUGGEL, Carlos; LÓPEZ, Marlon; PERLA, David; GONZALEZ, Victor; SCHULIN, Rainer. Soil cadmium uptake by cocoa in Honduras. In: Science of the Total Environment. 2018. vol. 612, p. 370-378. http://doi.org//0.1016/j. scitotenv.2017.08.145

20. HUAMANÍ-YUPANQUI, Hugo Alfredo; HUAUYA-ROJAS, Miguel Ángel; MANSILLA-MINAYA, Luis Germán; FLORIDA-ROFNER, Nelino; NEIRA-TRUJILLO, Gilmer Milton. Presencia de metales pesados en cultivo de cacao (Theobroma cacao L.) orgánico. In:Acta agronómica. 2012. vol. 6I, no. 4, p. 339-344. https://www.redalyc.org/ pdf//699//6992683/006.pdf

21. INTERNATIONAL COCOA ORGANIZATION - ICCO. Quarterly Bulletin of Cocoa Statistics, Vol. XLIV, No. 2, 2018. Cocoa year 2017//8. http://www.icco.org/about-cocoa/growing-cocoa.html

22. IGAC (Instituto Geográfico Agustín Codazzi). Estudio General de Suelos y Zonificación de Tierras del Departamento del Magdalena. Bogotá. 2009. 496 p.

23. INIAP - PROMSA. Determinación de metales contaminantes en cultivos de exportación y su repercusión sobre la calidad de los mismos. Informe Técnico 2003. Dpto. Suelos. Quevedo, Los Ríos, Ecuador. $60 \mathrm{p}$.

24. JACKSON, Marion LeRoy. Soil chemical analysis: Advanced course. UW-Madison Libraries Parallel Press. 2005. 930 p.

25. JIMÉNEZ, Claudia Stella. Estado legal mundial del cadmio en cacao (Theobroma cacao): fantasía o realidad. In: Producción+ Limpia. 2015. vol. I0, no. I, p. 89-104.

26. KONGOR, John Edem; HINNEH, Michael; VAN DE WALLE, David; AFOAKWA, Emmanuel Ohene; BOECKX, Pascal; DEWETTINCK, Koen. Factors influencing quality variation in cocoa (Theobroma cacao) bean flavour profile - A review, In: Food Research International. 2016. vol. 82, p. 44-52. https://doi.org/10.1016/j.foodres.2016.01.012

27. LANZA, José Gregorio; CHURIÓN, Pedro Cesar; LIENDO, Nelson José; LÓPEZ, Víctor Hugo. Evaluación del contenido de metales pesados en cacao (Theobroma cacao L.) de santa bárbara del Zulia, Venezuela. En: Saber. 2016. vol. 28, no. I, p. 106-II5. https://www. redalyc.org/pdf/4277/4277462760/2.pdf

28. LARA-VIVEROS, Francisco Marcelo; VENTURA-MAZA, Alejandro; EHSAN, Muhammad, RODRÍGUEZ-ORTEGA, Alejandro; VARGASMONTER, Jorge; LANDERO-VALENZUELA, Nadia. Contenido de $\mathrm{Cd}$ y $\mathrm{Pb}$ en suelo y plantas de diferentes cultivos irrigados con aguas residuales en elValle del Mezquital, Hidalgo, México. En: Revista internacional de contaminación ambiental. 20I5. vol 3I, no. 2, p. I27132. http://www.scielo.org.mx/pdf/rica/v3 $\ln 2 / v 3 \ln 2 \mathrm{a} 2 . p d f$

29. LONDOÑO-FRANCO, Luis Fernando; LONDOÑO-MUÑOZ, Paula Tatiana; MUÑOZ-GARCÍA, Fabián Gerardo. Los riesgos de los metales pesados en la salud humana y animal. En: Biotecnología en el Sector Agropecuario y Agroindustrial. 2016. vol. I4, no. 2, p. I45-I53. https://doi.org//0.18684/BSAA(14)|45-153

30. MARTíNEZ, Genny; PALACIO, Carolina. Determinación de metales pesados cadmio y plomo en suelos y granos de cacao fresco y fermentado mediante espectroscopia de absorción atómica de llama. 
Tesis de Pregrado. Universidad Industrial de Santander. 2010. Facultad de Ciencias. Escuela de Química. Bucaramanga. http://noesis.uis.edu. co/bitstream//23456789/3703////36 I I5.pdf

3I. MIRANDA, Diego; CARRANZA, Carlos; ROJAS, Carlos Andrés; JEREZ, Carlos Martín; FISCHER, Gerhard ZURITA,Jorge. Acumulación de metales pesados en suelos y plantas de cuatro cultivos hortícolas, regados con agua del río Bogotá. En: Rev. Colomb. Cienc. Hortíc. 2008. vol. 2, no. 2, p. 180-191. https://doi.org//0.17584/rcch.2008v2i2.1/86

32. MITE, Francisco; CARRILLO, Manuel; DURANGO, Wuellins. Avances del monitoreo de presencia de cadmio en almendras de cacao, suelos y aguas en Ecuador. In XII congreso Ecuatoriano de la Ciencia del suelo. 2010. vol. I, Pp. I.2I. http://www.secsuelo.org/wp-content/ uploads/2015/06/6.-Francisco-Mite.-Cadmio.-INIAP.pdf

33. OLIVARES-RIEUMONT, Susana; GARCÍA-CÉSPEDES, Damarys; LIMA-CAZORLA, Lazaro; SABORIT-SÁNCHEZ, Israel; LLIZOCASALS Axel, \& PÉREZ-ALVAREZ, Pedro. Niveles de cadmio, plomo, cobre y zinc en hortalizas cultivadas en una zona altamente urbanizada de la ciudad de la Habana, Cuba. En: Rev. Int. Contam. Ambient. 2013.vol.29, no. 4, p. 285-294. http://www.scielo.org.mx/pdf/ rica/v29n4/v29n4a6.pdf

34. PERNÍA, Beatriz; DE SOUSA, Andrea; REYES, Rosa; CASTRILLO, Marisol. Biomarcadores de contaminación por cadmio en las plantas. En: Interciencia. 2008. vol. 33, no. 2, p. I I2-I 19. https://www.redalyc. org/pdf/339/33933205.pdf

35. PIRANEQUE, Nelson.; AGUIRRE, Sonia., \& REIS, Adriano. Green manure: Alternative to carbon sequestration in a Typic Ustipsamment under semiarid conditions. In: Spanish Journal of Soil Science. 2018. vol. 8, no. 3, p. 293-305. https://www.researchgate. net/publication/330215222_Green_manure_Alternative_to carbon_sequestration_in_a_typic_ustipsamment_under_semiarid_ conditions

36. RAMÍREZ GIL, Joaquin Guillermo. Economic losses associated with cocoa pod rots caused by Phytophthora spp. and Moniliophthora roreri (Cif \& Par) Evans et al., at Theobroma farm, Colombia. In: Revista de Protección Vegetal. 2016. vol 31, no. I, p. 42-49. http:// scielo.sld.cu/pdf/rpv/v3/n|/rpv06||6.pdf

37. RAMTAHAL, Gideon; CHANG, Ivan; HAMID, Alisha; BEKELE, Isaac; BEKELE, Frances; MAHARAJ, Kamaldeo; HARRYNANAN, Lisa. The Effect of Liming on the Availability of Cadmium in Soils and Its Uptake in Cacao (Theobroma Cacao L.) In Trinidad \& Tobago. In: Communications in Soil Science and Plant Analysis. 2018. Vol 49, no. 19, p. 2456-2464, https://doi.org/10.1080/00103624.2018.1510955

38. RAMTAHAL, Gideon; CHANG, Ivan; AHMAD, Nazeer; BEKELE, Isaac; BEKELE, Frances; MAHARAJ, Kamaldeo; WILSON, Lawrence; HARRYNANAN, Lisa. Prediction of Soil Cadmium Bioavailability to Cacao (Theobroma cacao L.) using Single-Step Extraction Procedures. In: Communications in Soil Science and Plant Analysis. 2015. vol. 46, no. 20, p. 2585-2594. https://doi.org// 0.1080/00103624.2015.1089262

39. ROBERTS, Terry. Cadmium and phosphorous fertilizers: the issues and the science. In: Procedia Engineering. 2014. vol.83, p. 52-59. https://doi.
40. R. Team. R: a language and environment for statistical computing, $R$ Foundation for Statistical Computing, edited by RDC Team. $R$ Foundation for Statistical Computing (R Foundation for Statistical Computing),Vienna. 2015. URL: https://www.r-project.org/alt-home/

41. SALAMA, Ahmed. Health risk assessment of heavy metals content in cocoa and chocolate products sold in Saudi Arabia, Toxin Reviews. 2019. vol. 38, no. 4, p. 318-327. https://doi.org//0.1080/I5569543.20I 8.1471090

42. SILVEIRA, Maria Lucia Azevedo; ALLEONI, Luís Reynaldo Ferracciú; GUILHERME, Luiz Roberto Guimarães. Biosolids and heavy metals. In: soils. Sci. agric. (Piracicaba, Braz.). 2003. Vol. 60, no. 4, p. 793-806. https://doi.org//0.1590/S0103-90162003000400029

43. SOLTI, Ádám; SÁRVÁRI, Éva; TÓTH, Brigitta: BASA, Brigitta; LÉVAI, Lászlo; FODOR, Ferenc. Cd affects the translocation of some metals either Fe-like or Ca-like way in poplar. Plant Physiology and Biochemistry. 20I I. vol. 49, no. 5, p. 494-498. https://doi.org/10.1016/j. plaphy.2011.01.011

44. U.S EPA. Method 3050B: Acid digestion of sediments, sludges, and soils. Environmental Protection Agency:Washington, DC, USA. 1996. http://www.cornerstonelab.com/cornerstonewebsite2/SW-Methods/ PDFS/3050b.pdf

45. WANG, Lin; CUI Xiangfen; CHENG, Hongguang, CHEN, Fei;WANG, jiantong; ZAO, Xinyi; LIN, Chunye; PU, Chiao. A review of soil cadmium contamination in China including a health risk assessment. In: Environ Sci Pollut Res. 2015. vol. 22, p. 1644I-16452. https://doi. org/|0.1007/s ||356-0|5-5273-| 


\section{Appendix}

Appendix I.

Heavy metal content in the cocoa beans, shells and leaves from cocoa-producing areas in northern Colombia.

\begin{tabular}{|c|c|c|c|c|c|c|c|c|c|}
\hline \multirow{2}{*}{ Plot } & \multirow{2}{*}{ Zone } & \multirow{2}{*}{$\begin{array}{c}\text { Plant } \\
\text { material }\end{array}$} & $\mathrm{Ca}$ & $\mathrm{Mg}$ & $\mathrm{K}$ & $\mathrm{Cd}$ & $\mathrm{Pb}$ & $\mathrm{Ni}$ & $\mathrm{Cr}$ \\
\hline & & & \multicolumn{3}{|c|}{$\mathrm{g} \mathrm{kg}^{-1}$} & \multicolumn{4}{|c|}{$\mathrm{mg} \mathrm{kg}^{-1}$} \\
\hline \multirow{3}{*}{1} & 1 & Bean & 1.33 & 3.73 & 15.42 & $0.69^{*}$ & 0.49 & 12.66 & 13.3 \\
\hline & 1 & Shell & 11.15 & 4.10 & 24.5 & 0.38 & 0.26 & 2.99 & 0.67 \\
\hline & 1 & Leaf & 19.79 & 6.86 & 15.5 & 0.43 & 2.12 & 4.03 & 1.09 \\
\hline \multirow{3}{*}{2} & 1 & Bean & 1.76 & 4.41 & 19.71 & $0.72^{*}$ & 0.58 & 17.6 & 15.9 \\
\hline & 1 & Shell & 10.37 & 4.35 & 30.02 & 0.23 & 7.46 & 5.00 & 1.98 \\
\hline & 1 & Leaf & 17.07 & 5.37 & 19.45 & 0.35 & 1.20 & 2.56 & 0.75 \\
\hline \multirow{3}{*}{3} & 1 & Bean & 1.86 & 4.19 & 20.20 & $0.96^{*}$ & 3.44 & 16.4 & 0.96 \\
\hline & 1 & Shell & 6.18 & 3.30 & 29.13 & 0.15 & 0.87 & 5.13 & 1.38 \\
\hline & 1 & Leaf & 14.15 & 5.34 & 26.54 & 0.25 & 4.61 & 5.46 & 1.93 \\
\hline \multirow{3}{*}{4} & 1 & Bean & 0.79 & 4.11 & 19.82 & 0.46 & 1.86 & 6.26 & 1.29 \\
\hline & 1 & Shell & 7.98 & 3.76 & 30.98 & 0.20 & 0.61 & 3.94 & 1.53 \\
\hline & 1 & Leaf & 7.98 & 6.01 & 21.90 & 0.15 & 0.26 & 4.96 & 1.34 \\
\hline \multirow{3}{*}{5} & 1 & Bean & 0.99 & 3.64 & 15.17 & $0.46^{*}$ & 1.62 & 6.06 & 1.21 \\
\hline & 1 & Shell & 7.82 & 3.62 & 29.17 & 0.16 & 0.92 & 4.34 & 1.24 \\
\hline & 1 & Leaf & 19.08 & 8.55 & 14.26 & 0.81 & 1.42 & 8.93 & 1.03 \\
\hline \multirow{3}{*}{6} & 1 & Bean & 1.14 & 3.37 & 18.75 & 0.21 & 0.47 & 8.54 & 0.90 \\
\hline & 1 & Shell & 3.04 & 2.7 & 27.76 & 0.55 & 0.32 & 4.91 & 1.87 \\
\hline & 1 & Leaf & 12.4 & 6.94 & 21.57 & 0.73 & 2.6 & 6.33 & 1.33 \\
\hline \multirow{3}{*}{7} & 1 & Bean & 1.58 & 4.26 & 15.23 & 0.25 & 0.98 & 7.87 & 0.92 \\
\hline & 1 & Shell & 8.94 & 5.37 & 29.01 & 0.53 & 0.30 & 3.76 & 3.17 \\
\hline & 1 & Leaf & 10.85 & 5.20 & 28.89 & 0.19 & 2.09 & 3.44 & 1.05 \\
\hline \multirow{3}{*}{8} & 1 & Bean & 0.83 & 3.81 & 14.42 & 0.30 & 0.71 & 7.32 & 0.89 \\
\hline & 1 & Shell & 6.72 & 3.07 & 39.33 & 0.12 & 0.22 & 2.26 & 2.13 \\
\hline & 1 & Leaf & 18.66 & 7.35 & 14.31 & 0.27 & 2.87 & 2.95 & 2.04 \\
\hline \multirow{3}{*}{9} & 1 & Bean & 0.69 & 3.47 & 14.92 & 0.37 & 0.28 & 8.08 & 2.53 \\
\hline & 1 & Shell & 4.05 & 4.57 & 57.6 & 0.28 & 0.06 & 4.75 & 0.83 \\
\hline & 1 & Leaf & 17.4 & 8.02 & 15.24 & 0.61 & 0.3 & 4.89 & 0.65 \\
\hline \multirow{3}{*}{10} & 1 & Bean & 0.72 & 3.80 & 14.44 & $0.68^{*}$ & 0.48 & 6.77 & 2.48 \\
\hline & 1 & Shell & 2.77 & 2.65 & 41.66 & 0.56 & 0.10 & 5.25 & 1.22 \\
\hline & 2 & Leaf & 19.63 & 7.33 & 18.78 & 0.52 & 0.28 & 4.45 & 0.51 \\
\hline \multirow{3}{*}{11} & 2 & Bean & 1.20 & 3.87 & 20.99 & 1.01 & 0.57 & 9.76 & 0.73 \\
\hline & 2 & Shell & 15.53 & 7.98 & 19.75 & 0.24 & 0.28 & 2.10 & 0.39 \\
\hline & 2 & Leaf & 17.57 & 5.91 & 13.85 & 1.24 & 0.68 & 5.78 & 1.60 \\
\hline \multirow{3}{*}{12} & 2 & Bean & 0.96 & 4.04 & 16.95 & $0.71^{*}$ & 0.80 & 7.71 & 1.45 \\
\hline & 2 & Shell & 11.00 & 4.62 & 29.35 & 0.22 & 0.55 & 4.22 & 2.86 \\
\hline & 2 & Leaf & 13.10 & 5.82 & 15.56 & 0.19 & 0.54 & 3.13 & 1.71 \\
\hline
\end{tabular}




\begin{tabular}{|c|c|c|c|c|c|c|c|c|c|}
\hline \multirow{2}{*}{ Plot } & \multirow{2}{*}{ Zone } & \multirow{2}{*}{$\begin{array}{c}\text { Plant } \\
\text { material }\end{array}$} & $\mathrm{Ca}$ & $\mathrm{Mg}$ & $\mathrm{K}$ & $\mathrm{Cd}$ & $\mathrm{Pb}$ & $\mathrm{Ni}$ & $\mathrm{Cr}$ \\
\hline & & & \multicolumn{3}{|c|}{$\mathrm{g} \mathrm{kg}^{-1}$} & \multicolumn{4}{|c|}{$\mathrm{mg} \mathrm{kg}^{-1}$} \\
\hline \multirow{3}{*}{13} & 2 & Bean & 1.01 & 3.99 & 12.84 & $0.68^{*}$ & 1.13 & 15.5 & 0.95 \\
\hline & 2 & Shell & 9.30 & 4.68 & 26.37 & 0.13 & 9.00 & 6.89 & 2.46 \\
\hline & 2 & Leaf & 21.25 & 7.73 & 14.56 & 0.59 & 0.53 & 6.41 & 0.91 \\
\hline \multirow{3}{*}{14} & 2 & Bean & 1.41 & 3.69 & 13.82 & 0.18 & 0.60 & 5.04 & 1.60 \\
\hline & 2 & Shell & 9.08 & 3.22 & 23.93 & 0.87 & 0.72 & 5.99 & 1.32 \\
\hline & 2 & Leaf & 10.69 & 5.65 & 24.44 & 0.40 & 0.51 & 3.08 & 1.38 \\
\hline \multirow{3}{*}{15} & 2 & Bean & 1.08 & 4.00 & 16.68 & $0.86^{*}$ & 0.41 & 13.06 & 1.85 \\
\hline & 2 & Shell & 18.00 & 6.28 & 16.80 & 0.74 & 0.75 & 4.40 & 0.45 \\
\hline & 2 & Leaf & 18.35 & 7.47 & 14.54 & 0.15 & 0.59 & 4.34 & 0.90 \\
\hline \multirow{3}{*}{16} & 2 & Bean & 1.46 & 4.76 & 18.62 & 0.15 & 0.38 & 16.02 & 1.06 \\
\hline & 2 & Shell & 12.08 & 4.43 & 28.49 & 0.41 & 3.65 & 4.04 & 2.89 \\
\hline & 2 & Leaf & 16.50 & 6.00 & 15.45 & 0.28 & 0.51 & 2.12 & 1.26 \\
\hline \multirow{3}{*}{17} & 2 & Bean & 1.77 & 4.53 & 14.13 & 1.25 & 0.53 & 14.64 & 1.40 \\
\hline & 2 & Shell & 15.36 & 4.47 & 21.66 & 0.33 & 0.32 & 2.69 & 0.63 \\
\hline & 2 & Leaf & 14.6 & 6.38 & 12.61 & 0.20 & 0.43 & 2.37 & 0.78 \\
\hline \multirow{3}{*}{18} & 2 & Bean & 2.27 & 3.91 & 14.48 & $0.43^{*}$ & 0.34 & 6.58 & 0.98 \\
\hline & 2 & Shell & 14.92 & 3.95 & 17.86 & 0.24 & 0.67 & 4.65 & 1.13 \\
\hline & 2 & Leaf & 15.42 & 7.23 & 13.78 & 0.35 & 0.52 & 2.39 & 0.61 \\
\hline \multirow{3}{*}{19} & 2 & Bean & 3.36 & 3.79 & 16.85 & $0.76^{*}$ & 0.36 & 11.54 & 1.12 \\
\hline & 2 & Shell & 16.07 & 4.18 & 19.25 & 0.52 & 0.67 & 2.14 & 1.24 \\
\hline & 2 & Leaf & 10.23 & 4.87 & 20.7 & 0.35 & 0.50 & 8.73 & 0.78 \\
\hline \multirow{3}{*}{20} & 2 & Bean & 1.66 & 4.84 & 20.59 & $0.62^{*}$ & 0.37 & 10.84 & 0.64 \\
\hline & 2 & Shell & 1.20 & 3.94 & 21.04 & 0.37 & 0.70 & 2.98 & 0.97 \\
\hline & 2 & Leaf & 15.53 & 5.91 & 14.78 & 0.32 & 0.67 & 4.82 & 0.61 \\
\hline
\end{tabular}

